\title{
PHYTOPLANKTON SUCCESSION IN AN ARTIFICIAL, PERIODICALLY DRAINED SMALL WATER BODY
}

\author{
Sofia Celewicz-Gołdyn, Aneta Dotka \\ S. Celewicz-Gołdyn, A. Dotka, Department of Botany, Poznań University of Life Sciences, Wojska Polskiego \\ 71 C, 60-625 Poznań, Poland, e-mail: celewicz@up.poznan.pl
}

(Received: July 22, 2014. Accepted: September 26, 2014)

\begin{abstract}
Aвstract. This study was undertaken to monitor the course of a secondary succession of phytoplankton in temporary water bodies, based on a man-made periodically drained pond. Results of phycological analyses showed, that small Chlorophyceae from the order Chlorococcales predominated qualitatively throughout the study period. Chlorophyceae, e.g. stress-resistant Haematococcus pluvialis, developed best as the first algae (after the pond was re-filled). In the next stages of diatom succession (Ulnaria ulna) predominated quantitatively, followed by the longest period of Cyanobacteria (Aphanothece elabens) predominance, replaced again by Chlorophyceae (Tetraëdron minimum and Oocystis lacustris). Total abundance of algae, similarly as that of Cyanobacteria, were positively correlated with temperature and $\mathrm{pH}$ of water.
\end{abstract}

Key words: Cyanobacteria, Chlorophyceae, Chlorococcales, Haematococcus pluvialis, Aphanothece elabens, pond

\section{INTRODUCTION}

Small water bodies are characterised by rapid succession processes of organisms colonising them, such as e.g. phytoplankton. Due to the limited depth and size of these water bodies they offer conditions conducive to the development of planktonic algae (rapid heating of water, advantageous access to light, abundance of nutrients and their easy transfer to the productive surface zone). Additionally, frequently drained water bodies due to their intermittent character create habitats distinctly different from those found in permanent waters. Periodical drainage of water, removal of vegetation and bottom sediments are major factors modifying succession processes in these ecosystems (FALKOWSKI \& NOWICKA-FALKOWSKA 2006 a, b).

The phytoplankton of temporary waters is very specific, dominated by species adopted to variable and often extreme environmental conditions (MARRONE et al. 2006, NAselli-Flores \& Barone 2012). Local instability may promote the exceptionally high species richness frequently observed in ephemeral habitats. The individual and interacting impacts of factors influencing community structure and dynamics in temporary ponds are largely unknown (WATERKEYn et al. 2008, NAselli-Flores \& Barone 2012, BLANCO et al. 2013).
Following re-filling of a water body the phytoplankton community is re-established, originating mainly from spores contained at the bottom. This process of colonisation seems to be crucial for the future shape of the community.

An example of such water bodies is provided by a small, man-made water body located at the Collegium Maximum building of the Poznan University of Life Sciences, which was created in order to enhance the aesthetic value of the campus area. Every year in the summer season a relatively rapid deterioration of water quality is observed, caused by blooms of planktonic Chlorophyceae (unpublished data).

The aim of this study was to monitor the succession of algae from the moment the pond was re-filled with water and to determine the effect of such factors as $\mathrm{pH}$ and temperature of water on algal development.

\section{STUDY AREA}

The man-made pond investigated in this study is located at the campus of the Poznan University of Life Sciences, at Wojska Polskiego street behind the Collegium Maximum building (Fig. 1).

Every year it is filled with water for the period from April to November and then it is drained. The 


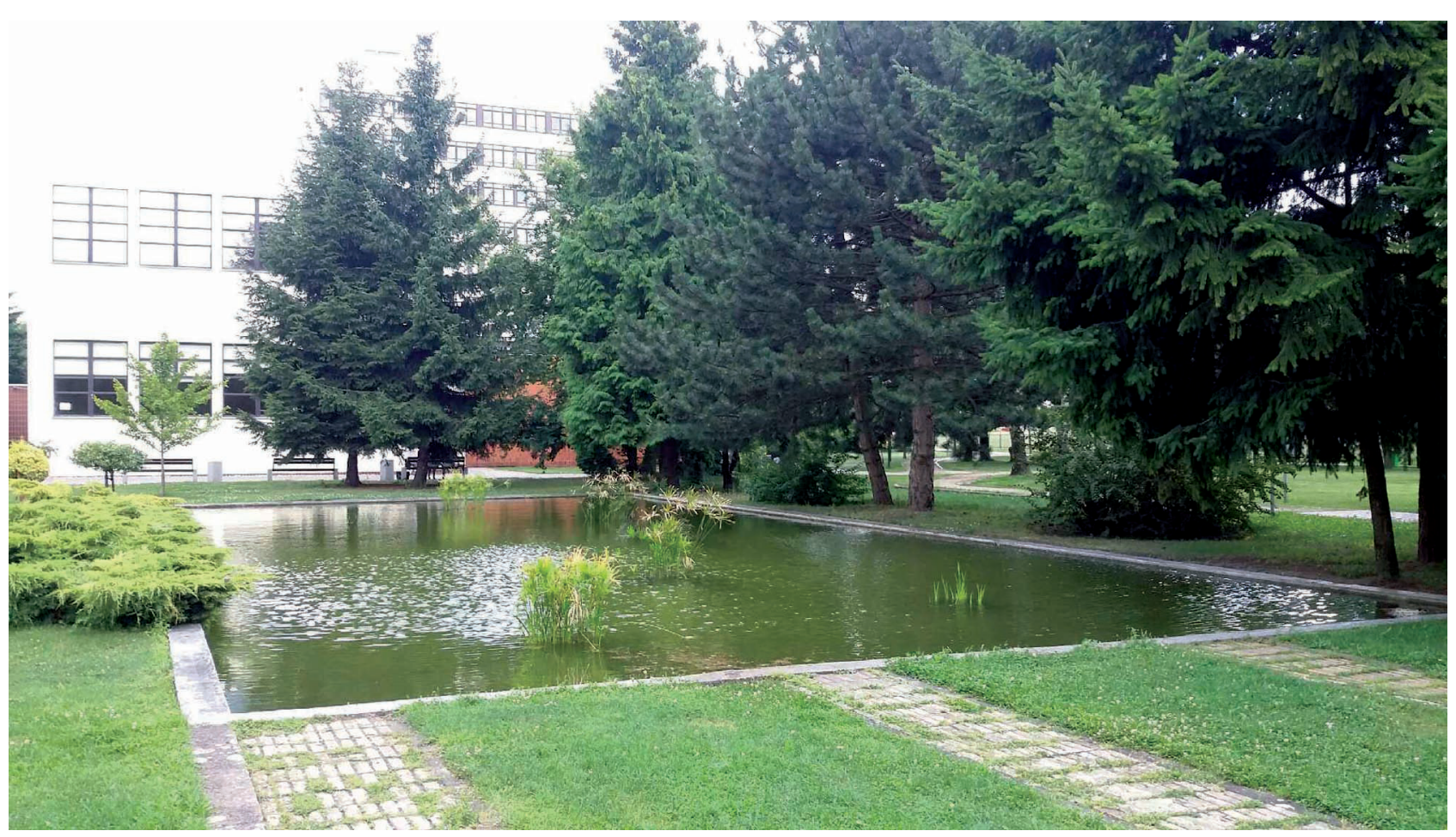

Fig. 1. View of the investigated water body in 2012 (Phot. M. Golcz-Polaszewska)

pond is $257 \mathrm{~m}^{2}$ and $0.5 \mathrm{~m}$ deep. Single vascular plant specimens (Cyperus papirus L., Nymphaea L.) are planted in the pond. Coniferous trees from the genera Pseudotsuga, Pinus and Thuja as well as scarce shrubs such as e.g. Berberis L. are growing in the vicinity of the water body. Crucian carps are released to the pond every year.

\section{MATERIALS AND METHODS}

Samples for the qualitative and quantitative analyses were collected 14 times, bi-weekly (between 24th April to 23th October, 2012), from the water surface layers. Each time water $\mathrm{pH}$ and temperature were measured using a digital $\mathrm{pH}$ meter (Hanna model). The samples for qualitative phytoplankton analyses were concentrated using a plankton net ( $40 \mu \mathrm{m}$ mesh size), and those for quantitative analyses were taken using plastic bottle (1 liter) and than fixed with Lugol's solution and concentrated to a volume of $5 \mathrm{ml}$ by sedimentation. They were analysed in the laboratory under a light microscope, using $20 \times$ and $40 \times$ objectives.

Taxonomic keys employed in the identification included: STARMACH 1966, 1968, 1974, 1989, HindáK 1984, 1988 a, b, 2005, Krammer \& Lange-Bertalot
1986, 1988, 1991 a, b, PopovskÝ \& Pfiester 1990, KomÁREK \& ANAGNOSTIDIS 1998.

The abundance of the phytoplankton was determined applying the Fuchs-Rosenthal chamber. Single cells and algal cenobia were treated as individual organisms. In the case of trichomes a single individual was considered to be $100 \mu \mathrm{m}$ long, and in the colony forming cyanobacteria Aphanothece elabens to cover the area of $400 \mu \mathrm{m}^{2}$.

The dominant taxa were defined as those accounting for $10 \%$ or more of the total phytoplankton abundance in a given sample.

To analyse the relationship between the phytoplankton abundance and physico-chemical water properties, the Spearman correlation coefficients were calculated (significance at $\mathrm{p}<0.05$ ). The data were processed with STATISTICA 6.0 PL 2002 software (STATISTICA... 2002).

\section{RESULTS AND DISCUSSION}

In the investigated water body, $\mathrm{pH}$ fluctuated between 6.3 and 10.3 , and temperature between $9.5^{\circ} \mathrm{C}$ and $22.5^{\circ} \mathrm{C}$ (Table 1). Considerable and rapid changes in pysico-chemical parameters of water are typical of small water bodies.

Table 1. Temporal changes in water $\mathrm{pH}$ and temperature in the investigated water body in 2012

\begin{tabular}{|c|c|c|c|c|c|c|c|c|c|c|c|c|c|c|}
\hline Date & 24.04 & 8.05 & 22.05 & 5.06 & 19.06 & 3.07 & 17.07 & 31.07 & 14.08 & 28.08 & 11.09 & 25.09 & 9.10 & 23.10 \\
\hline $\mathrm{pH}$ & 7.4 & 7.83 & 9 & 8.65 & 9.6 & 9.8 & 10.3 & 10.3 & 9.78 & 8.77 & 6.7 & 6.4 & 6.45 & 6.34 \\
\hline $\begin{array}{l}\text { Tempera- } \\
\text { ture }\left({ }^{\circ} \mathrm{C}\right)\end{array}$ & 12.5 & 14.7 & 20 & 14.3 & 21.5 & 22.5 & 17.9 & 21.5 & 17.3 & 17.1 & 17.3 & 12.1 & 9.5 & 10.2 \\
\hline
\end{tabular}


Table 2. Taxonomic composition of phytoplankton in the studied water body

\begin{tabular}{l}
\hline Cyanobacteria \\
\hline Aphanothece elabens (Brèbisson ex Meneghini) Elenkin \\
Chroococcus turgidus (Kützing) Nägeli \\
Johannesbaptistia sp. \\
Oscillatoria sp. \\
\hline Chlorophyceae \\
\hline Actinastrum hantzchii Lagerheim \\
Cosmarium rectangulare Grun. in Rabenhorst \\
Crucigenia tetrapedia Hindák \\
Haematococcus pluvialis Flotow \\
Oocystis borgei Snow \\
Oocystis lacustris Chodat \\
Pandorina morum Müller \\
Pediastrum boryanum (Turpin) Meneghini \\
Planktonema lauterbornii Schmidle \\
Scenedesmus dimorphus (Turpin) Kützing \\
Scenedesmus obliquus (Turpin) Kützing \\
Tetraedron minimum (A. Braun) Hansgirg \\
\hline Bacillariophyceae \\
\hline Amphora ovalis Kützing \\
Cymbella affinis Kützing \\
Gomphonema intricatum Kützing \\
Gomphonema truncatum Ehrenberg \\
Navicula radiosa Kützing \\
Nitzschia acicularis W. Sm. \\
Nitzschia palea Kützing \\
Rhopalodia gibba Ehrenberg \\
Ulnaria acus (Kützing) M. Aboal in Aboal \\
Ulnaria ulna (Nitzsch) P. Compère \\
\hline Dinophyceae \\
\hline Gymnodinium sp. \\
Katodinium sp. \\
Peridinium sp. \\
Woloszynskia pascheri (Suchlandt) von Stosch \\
\hline Chrysophyceae \\
\hline Synura sp. \\
\hline
\end{tabular}

Phycological studies revealed the presence of 31 phytoplankton species (Table 2), which belonged to five taxonomic groups (Cyanobacteria, Chlorophyceae, Bacillariophyceae, Dinophyceae and Chrysophyceae). In terms of taxa numbers, the Chlorophyceae was the dominant group (Fig. 3). Their share in the total number of phytoplankton taxa was 39\% (Fig. 2, 3). Among Chlorophyceae predominated the species from the order Chlorococcales, which develop well in shallow aquatic ecosystems, at the abundance of nutrients (REYNOLDS 1984, KaWECKa \& Eloranta 1994, Lee 1999, MarașlioĞLu et al. 2011, Nowrouzi \& Valavi 2011). Predominance of small planktonic forms is usually noted in the early stage of succession or in extreme habitats (CATALAN et al. 2006, Tavernini et al. 2009, PęCZuła et al. 2014). The share of Bacillariophyceae was also considerable $(32 \%)$. The highest number of algae taxa was recorded in the initial stages of succession (Fig. 3), shortly after the pond was filled with water. A similar trend was described by MichaLOUdI et al. (2012) who stated that phytoplankton species richness in a temporary lake increased within a few months after inundation. A reduction in the species number in July and August coincided with the massive development of Cyanobacteria and Chlorophyceae.

The highest frequency of the algae species in the analysed pond was recorded for a blue-green algae Aphanothece elabens and also such Chlorophyceae as Cosmarium rectangulare, Haematococcus pluvialis, Oocystis lacustris and Pediastrum boryanum. Among diatoms Rhopalodia gibba and Amphora ovalis, i.e. species preferring basic water reaction and fertile waters, were recorded most frequently (VAN DAM 1994, ANTÓN-GARRIDO et al. 2013).

Quantitative analysis of phytoplankton showed the predominance of Chlorophyceae in the spring and autumn seasons, while in the summer period (19.06-28.08) Cyanobacteria constituted a vast majority (Fig. 4, 5). The share of diatoms in the initial sampling period increased up to June 5th (Fig. 4). In the later period of the study water temperature increased considerably and then diatoms were replaced by cyanobacteria. According to NowrouzI \& VALAVI (2011) and LúRLING et al. (2013), diatoms are adapted to lower temperatures than cyanobacteria. Literature data also indicate that the quantitative development of Bacillariophyceae occurs in the spring period in conditions of low water temperatures (REYNOLDS 1996, MutshindA et al. 2013), high water turbidity, and low availability of light. Nitzschia palea and Ulnaria ulna were found in the greatest numbers in the initial stage of sample collection. These diatoms are indicators of fertile and contaminated waters (VAN DAM 1994, TROBAJo et al. 2009). Starting from the time the pond was re-filled an upward trend was observed for the

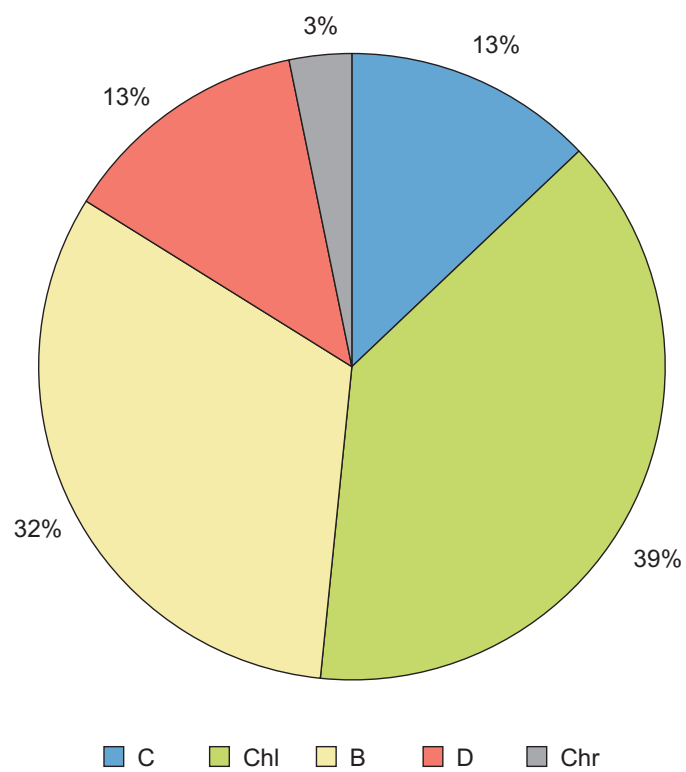

Fig. 2. Percentage contributions of particular systematic groups to the number of phytoplankton taxa in the investigated water body in 2012 (C - Cyanobacteria, Chl Chlorophyceae, B - Bacillariophyceae, D - Dinophyceae, Chr - Chrysophyceae) 


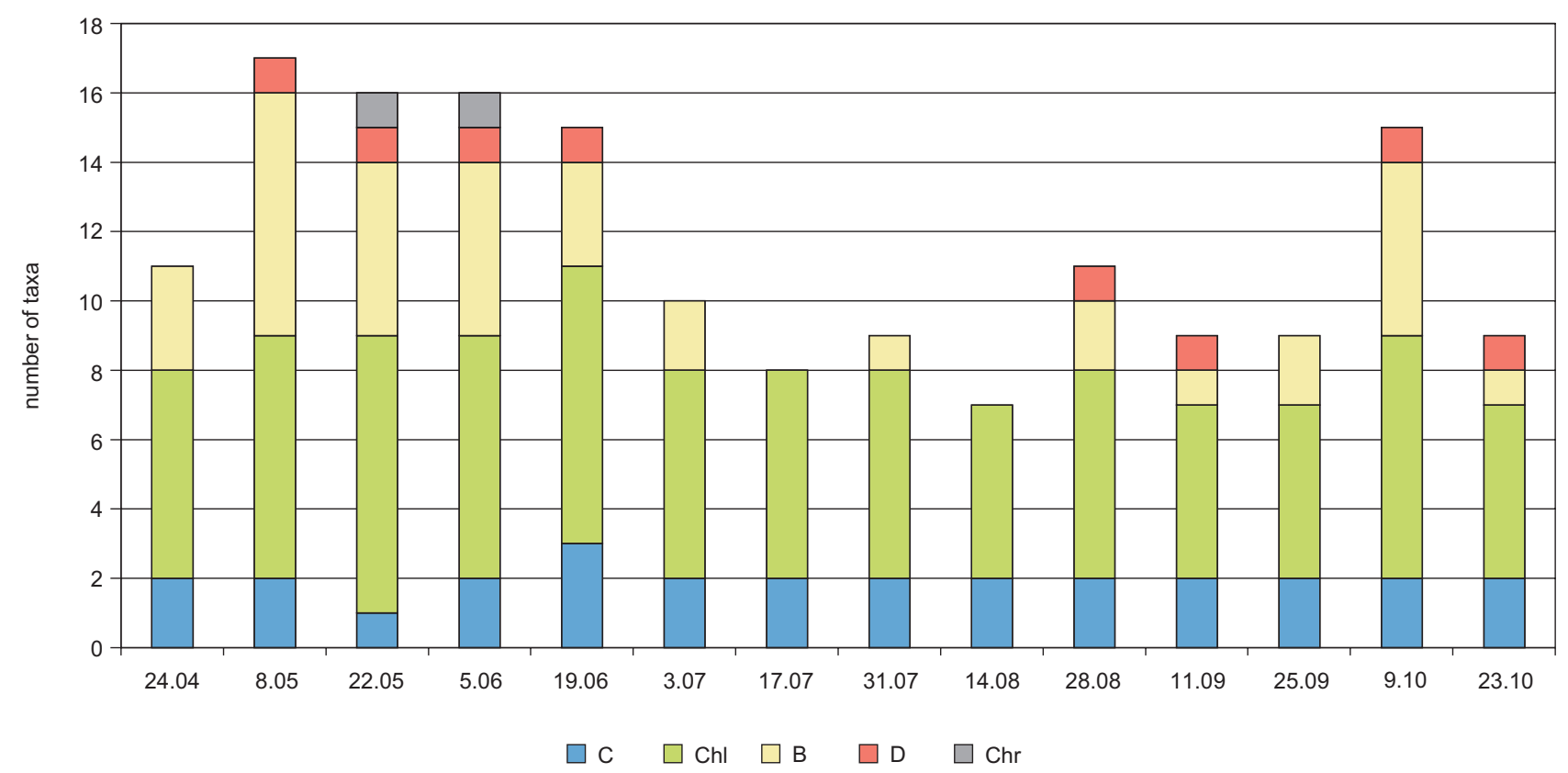

Fig. 3. Temporal changes in the number of phytoplankton taxa in the investigated water body in 2012 (C - Cyanobacteria, Chl - Chlorophyceae, B - Bacillariophyceae, D - Dinophyceae, Chr - Chrysophyceae)

total abundance of algal specimens until mid-July, followed by a downward trend. The maximum number of individuals was 5736 indiv. $/ \mathrm{ml}$ and it was recorded on 17.07.2012, when the abundance of Cyanobacteria was also highest in the entire sampling period (3740 indiv./ml, Fig. 5). The increase in the total number of phytoplankton individuals, including Cyanobacteria, was connected with an increase in temperature and $\mathrm{pH}$ of water in the summer period. This was confirmed by sta- tistical analyses, which showed significant positive correlations between water temperature and the phytoplankton and Cyanobacteria abundance $(r=$ 0.606 and $r=0.712$, respectively) and dominant species: Aphanothece elabens and Oocystis lacutris ( $\mathrm{r}$ $=0.747$ and $\mathrm{r}=0.533$, respectively). According to Nowrouzi \& VALAVI (2011) chlorophytes increase under high temperatures, just as blue-green algae. Significant positive correlations were also recorded between $\mathrm{pH}$ and total abundance of phytoplank-

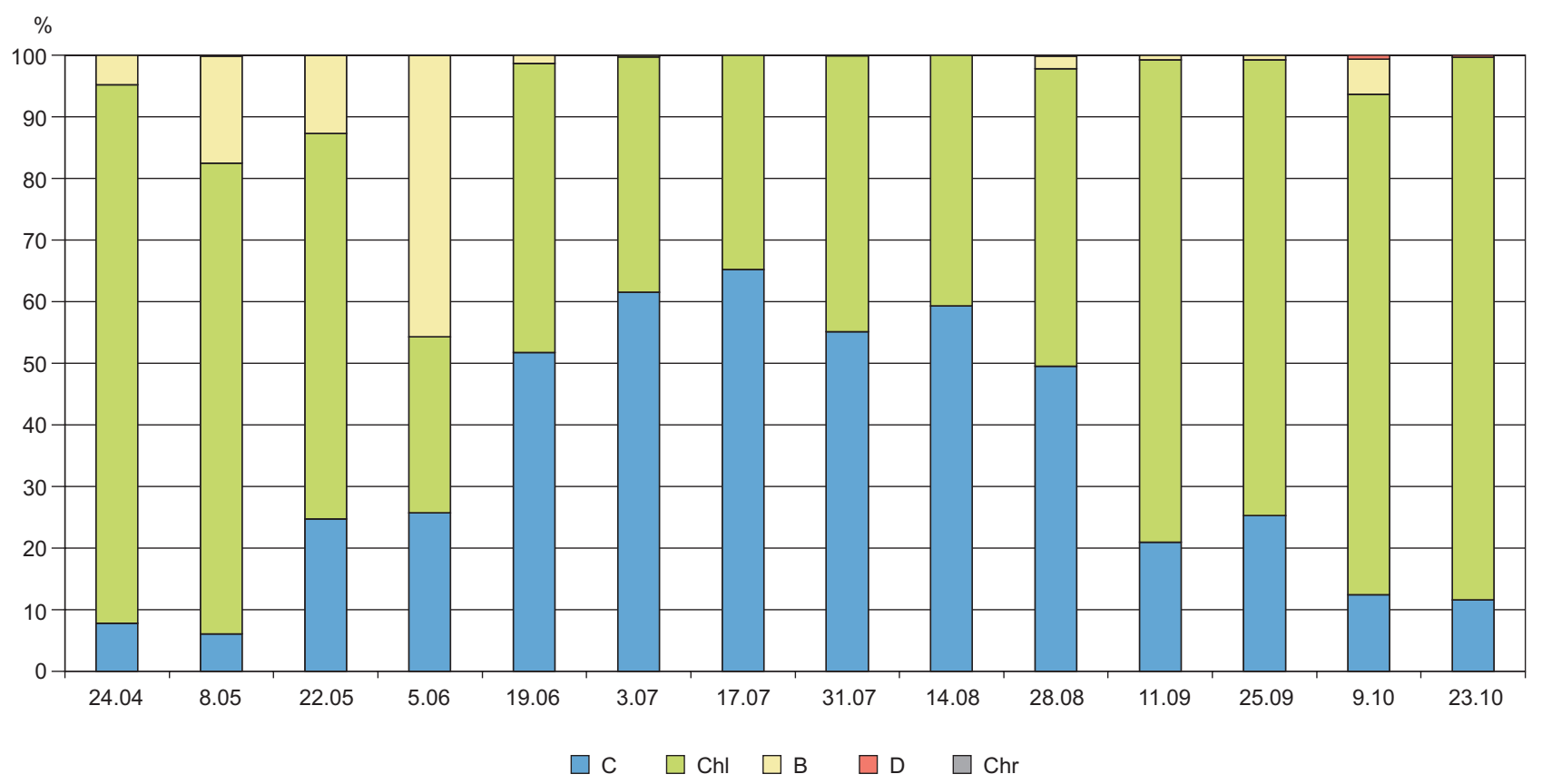

Fig. 4. Percentage contributions of particular systematic groups to the number of phytoplankton individuals in the studied water body in 2012 (C - Cyanobacteria, Chl - Chlorophyceae, B - Bacillariophyceae, D - Dinophyceae, Chr - Chrysophyceae) 


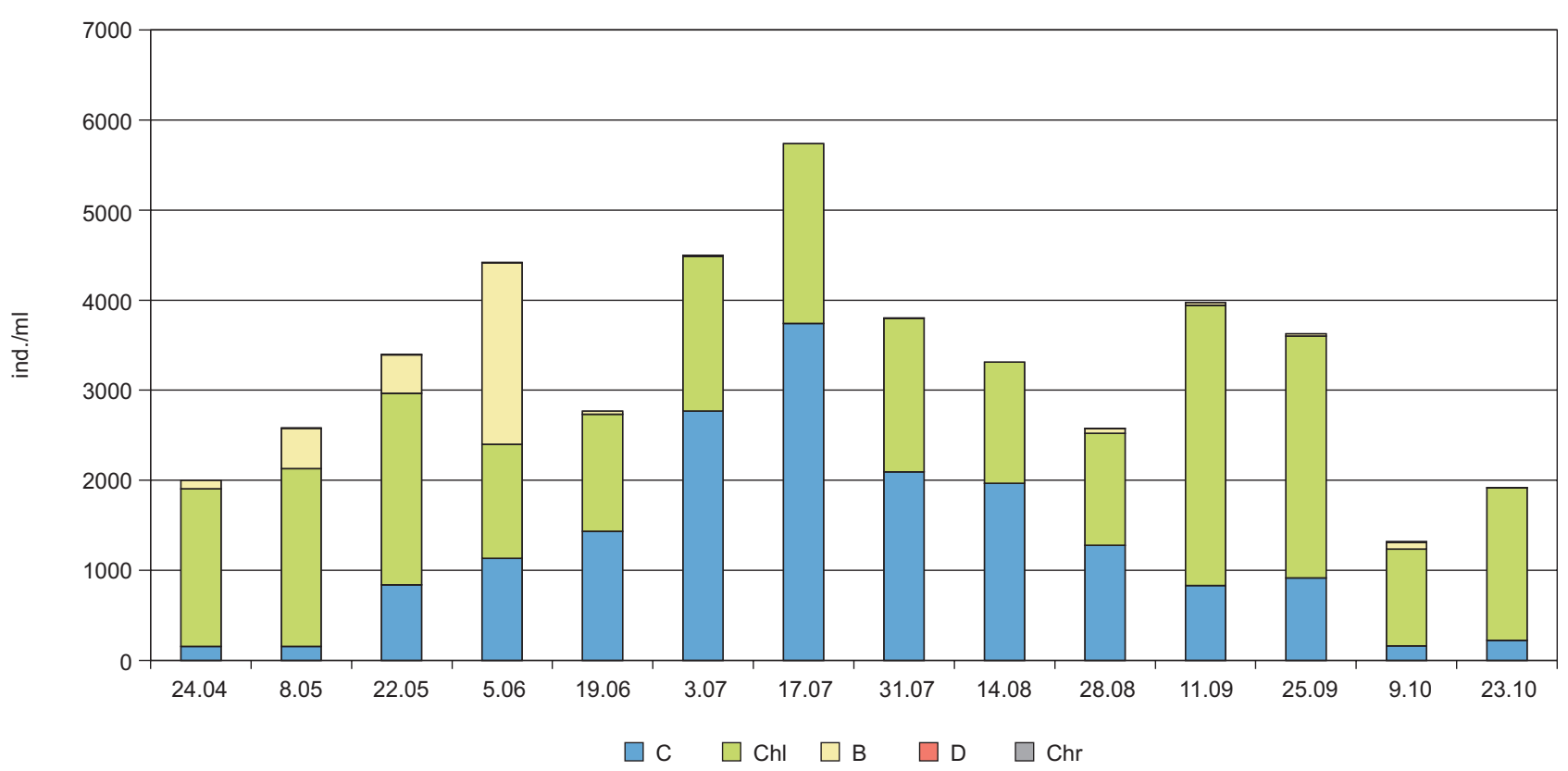

Fig. 5. Temporal changes of phytoplankton abundance in the studied water body in 2012 (C - Cyanobacteria, Chl - Chlorophyceae, B - Bacillariophyceae, D - Dinophyceae, Chr - Chrysophyceae)

Table 3. Structure of phytoplankton dominants in the investigated water body in 2012

\begin{tabular}{|c|c|c|c|c|c|c|c|c|c|c|c|c|c|c|}
\hline Species & 24.04 & 8.05 & 22.05 & 5.06 & 19.06 & 3.07 & 17.07 & 31.07 & 14.08 & 28.08 & 11.09 & 25.09 & 9.10 & 23.10 \\
\hline Haematococcus pluvialis & + & + & & & & & & & & & & & & \\
\hline Cosmarium rectangulare & & & + & & & & & & & & & & & \\
\hline Ulnaria ulna & & & & + & & & & & & & & & & \\
\hline Aphanothece elabens & & & & & + & + & + & + & + & + & & & & \\
\hline Tetraëdron minimum & & & & & & & & & & & + & & + & + \\
\hline Oocystis lacustris & & & & & & & & & & & & + & & \\
\hline
\end{tabular}

ton and Cyanobacteria $(\mathrm{r}=0.570$ and $\mathrm{r}=0.819$, respectively) and a species Aphanothece elabens ( $\mathrm{r}$ $=0.841)$. According to ReYNOLDs et al. 2002 this species, similarly as most Cyanobacteria, develops well in alkaline waters. Alternatively, increases in algal abundance may increasing $\mathrm{pH}$ (MutshinDA et al. 2013). In sum, changes in phytoplankton abundance often cause changes in environmental parameters.

The structure of dominant species in the analysed water body fluctuated with time (Table 3). Chlorophyceae predominated in the initial stage of

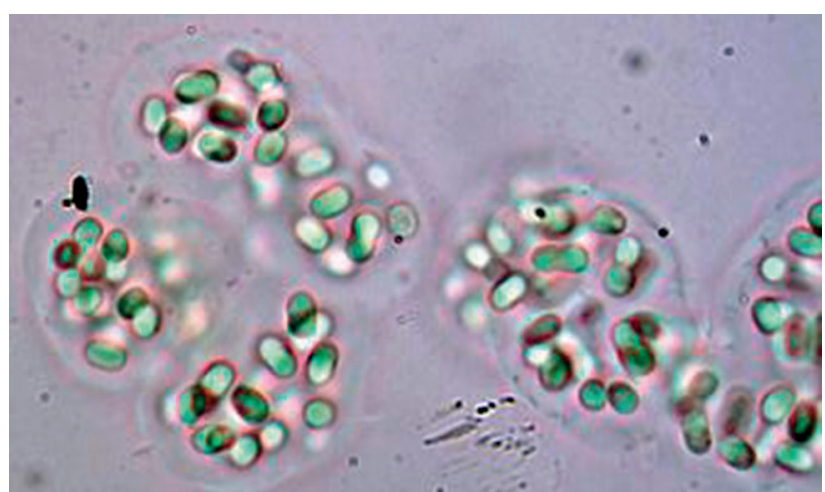

Fig. 6. Aphanothece elabens succession, followed successively by diatoms, $C y$ anobacteria (Aphanothece elabens, Fig. 6) and again Chlorophyceae. The first dominant species after the pond was re-filled with water was a green alga Haematococcus pluvialis (Fig. 7), a ubiquitous microalga occurring mainly in ephemeral small fresh water pools (KLOCHкоva et al. 2013). At that time a red water colouring was observed in the pond, caused by the accumulation of a ketocarotenoid astaxanthin in algal cells of Haematococcus pluvialis. Astaxanthin

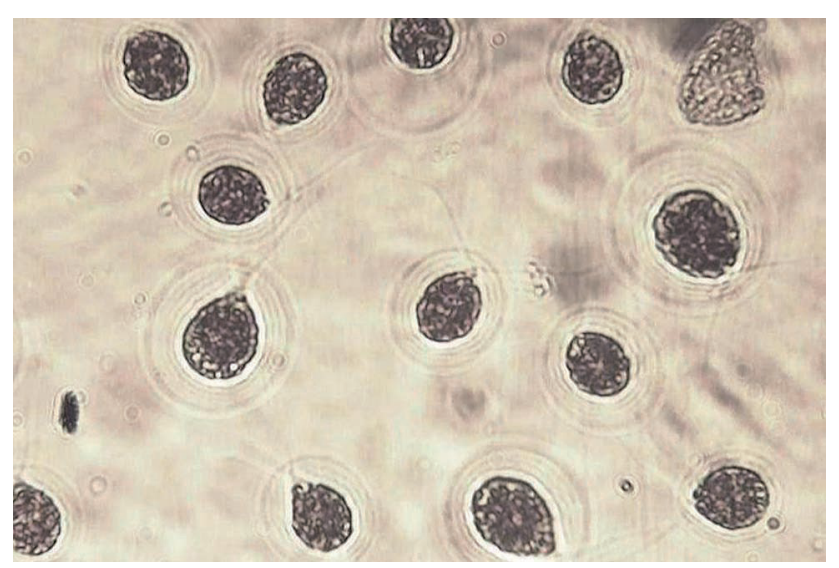

Fig. 7. Motile bi-flagellated cells of Haematococcus pluvialis 
accumulation in Haematococcus was reported to be induced under stress connected with unfavourable growth conditions such as nutrient deficiency ( $\mathrm{N}$ or $\mathrm{P})$, variations of temperature and other factors (Sarada et al. 2002, Dominguez-Bocanegra et al. 2004). Thanks to these characteristics Haematococcus pluvialis seems to be a good pioneering species in the initial stage of phytoplankton succession in the analysed water body.

A large share of Chlorophyceae and Cyanobacteria, in the analysed water body, as well as a considerable number of species preferring eutrophic waters, indicate high concentrations of nutrients in water. Moreover, the predominance of rapidly proliferating taxa with the $r$ type development strategy showed liable environmental conditions typical of shallow aquatic ecosystems. The primary cause for eutrophication and massive development of algae was connected most probably with the introduction of fish to the analysed water body. Feed for fish as well as fish droppings found in the water are considerable sources of biogens, greatly enriching water and stimulating algal development (SIPAÚBA-TAVAREs et al. 2011). An additional aspect promoting intensive development of phytoplankton was connected with the limited share of macrophytes, which compete with algae for light and nutrients (Kosten et al. 2011).

Undertaken investigations provided a contribution to the development of methods to prevent and/ or control algal blooms in such water bodies and will broaden our knowledge on the ecology of planktonic algae, pioneering species and the species resistant to environmental stress.

\section{REFERENCES}

Antón-Garrido B., Romo S., Villena M.J. (2013): Diatom species composition and indices for determining the ecological status of coastal Mediterranean Spanish lakes. Anales del Jardin Botánico de Madrid 70 (2): 122-135.

Blanco S., Álvarez-Blanco I., Cejudo-Figuerias C., Recio Espejo J.M., Borja Barrera C., Bècares E., Diaz del Olmo F., Cámara Artigas R. (2013): The diatom flora in temporary ponds of Doňana National Park (southwest Spain): five new taxa. Nordic Journal of Botany 31: 489-499.

Catalan J., Camarero L., Felip M., Pla S., Ventura M., Buchaca T., Bartumeus F., De Mendoza G., Miró A., CASAMAYOR E.O. (2006): High mountain lakes: extreme habitats and witnesses of environmental changes. Limnetica 25 (1-2): 551-584.

van Dam H., Mertens A., Sinkeldam J. (1994): A coded checklist and ecological indicator values of freshwater diatoms from the Netherlands. Netherlands Journal of Aquatic Ecology 28 (1): 117-133.

Dominguez-Bocanegra A.R., LegarReta I.G., Jeronimo F.M., CAmpocosio A.T. (2004): Influence of envi- ronmental and nutritional factors in the production of astaxanthin from Haematococcus pluvialis. Bioresource Technology 92: 209-214.

Falkowski M., Nowicka-FalKowska K. (2006 a): Szata roślinna stawów rybnych Niziny Południowopodlaskiej. Cz. 2. Związek Potamion [Vegetation cover in fish ponds in the Southern Podlasie Lowland. Part 2. The Potamion alliance]. Fragmenta Floristica et Geobotanica Polonica 13 (1): 95-112.

FalKowski M., Nowicka-FalKowska K. (2006 b): Szata roślinna stawów rybnych Niziny Południowopodlaskiej. Cz. 3. Związek Nymphaeion [Vegetation cover in fish ponds in the Southern Podlasie Lowland. Part 2. The Nymphaeion alliance]. Fragmenta Floristica et Geobotanica Polonica 13(2): 351-360.

HindÁK F. (1984): Studies on the Chlorococcal Algae (Chlorophyceae) III. VEDA Publishing House of the Slovak Academy of Sciences, Bratislava.

HINDÁK F. (1988 a): Studies on the Chlorococcal Algae (Chlorophyceae) IV. VEDA Publishing House of the Slovak Academy of Sciences, Bratislava.

Hindák F. (1988 b): Studies on the Chlorococcal Algae (Chlorophyceae) V. VEDA Publishing House of the Slovak Academy of Sciences, Bratislava.

KaWECKA B., Eloranta P.V. (1994): Zarys ekologii glonów wód słodkich i środowisk lądowych. Wyd. Nauk. PWN, Warszawa.

Klochkova T.A., Kwak M.S., Han J.W., Motomura T., Nagasato Сн., Kim G.H. (2013): Cold-tolerant strain of Haematococcus pluvialis (Haematococcaceae, Chlorophyta) from Blomstrandhalvøya (Svalbard). Algae 28 (2): 185-192.

KomÁrek J., Anagnostidis K. (1998): Cyanoprokaryota. 1. Teil: Chroococcales. Süsswasserflora von Mitteleuropa 19/1. Fischer Verlag, Stuttgart.

KomÁrek J., Anagnostidis K. (2005): Cyanoprokaryota. 2. Teil: Oscillatoriales. Süsswasserflora von Mitteleuropa 19/2. Elsevier GmbH, Spektrum Akademischer Verlag, Heidelberg.

Kosten S., Jeppesen E., Huszar V.L.M., Mazzeo N., van Nes E.H., Peeters E.T.H.M., Scheffer M. (2011): Ambiguous climate impacts on competition between submerged macrophytes and phytoplankton in shallow lakes. Freshwater Biology 56: 1540-1553.

Krammer K., Lange-Bertalot H. (1986): Bacillariophyceae. Süsswasserflora von Mitteleuropa. T. 2/1. VEB Gustav Fischer Verlag, Jena.

Krammer K., Lange-Bertalot H. (1988): Bacillariophyceae. Süsswasserflora von Mitteleuropa. T. 2/2. VEB Gustav Fischer Verlag, Jena.

Krammer K., Lange-Bertalot H. (1991 a): Bacillariophyceae. Süsswasserflora von Mitteleuropa. T. 2/3. VEB Gustav Fischer Verlag, Jena.

Krammer K., Lange-Bertalot H. (1991 b): Bacillariophyceae. Süsswasserflora von Mitteleuropa. T. 2/4. VEB Gustav Fischer Verlag, Jena. 
LeE R.E. (1999): Phycology. Cambridge University Press, Cambridge.

LỦrling M., Eshetu F., FaAssen E.J., Kosten S., Huszar V.L.M. (2013): Comparison of cyanobacterial and green algae growth rates at different temperatures. Freshwater Biology 58: 552-559.

MarașlioĞLu F., SoYlu E.N., GöNÜLOL A. (2011): Chlorococcal chlorophyte composition, community structure, and seasonal variations in the shallow lakes of the Kizilirmak Delta, Turkey. Turkish Journal of Botany 35: 117-124.

Marrone F., Barone R., Naselli-Flores L. (2006): Ecological characterization and cladocerans, calanoid copepods and large branchiopods of temporary ponds in a Mediterranean island (Sicily, Southern Italy). Chemistry and Ecology 22, Suppl. 1: 181-190.

Michaloudi E., Moustaka-Gouni M., Pantelidakis K., KatSiAPI M., Genitsaris S. (2012): Plankton succession in the temporary lake Koronia after intermittent dry-out. International Rewiev of Hydrobiology 97 (5): 405-419.

Mutshinda C.M., Troccoli-Ghinaglia L., Finkel Z.V., Müller-Karger F.E., IrWin A.J. (2013): Environmental control of the dominant phytoplankton in the Cariaco basin: a hierarchical Bayesian approach. Marine Biology Research 9: 247-261.

Naselli-Flores L., Barone R. (2012): Phytoplankton dynamics in permanent and temporary Mediterranean waters: is the game hard to play because of hydrological disturbance? Hydrobiologia 698: 147-159.

Nowrouzi S., Valavi H. (2011): Effects of environmental factors on phytoplankton abundance and diversity in Kaftar Lake. Journal of Fisheries and Aquatic Sciences 6 (2): 130-140.

Pęczuza W., Szczurowska A., Poniewozik M. (2014): Phytoplankton community in early stages of reservoir development - a case study from the newly formed, colored, and episodic lake of mining-subsidence genesis. Polish Journal of Environmental Studies 23 (2): 585-591.

Popovský J., Pfiester L.A. (1990): Dinophyceae (Dinoflagellida). Süsswasserflora von Mitteleuropa. T. 6. VEB Gustav Fischer Verlag. Heidelberg, Berlin.

REYNOLDS C.S. (1984): The ecology of freshwater phytoplankton. Cambridge University Press, Cambridge.
ReYnolds C.S. (1996): The plant life of the pelagic. Verhandlungen des Internationalen Verein Limnologie 26: 97-113.

Reynolds C.S., Huszar V., Kruk C., Naseli-Flores L., Melo S. (2002): Towards a functional classification of the freshwater phytoplankton. Journal of Plankton Research 24, 5: 417-428.

Sarada R., Tripathi U., Ravishankar G.A. (2002): Influence of stress on astaxanthin production in Haematococcus pluvialis grown under different culture conditions. Process Biochemistry 37: 623$-627$.

Sipaúba-Tavares L.H., Donadon A.R.V., Milan R.N. (2011): Water quality and plankton populations in an earthen polyculture pond. Brazilian Journal of Biology 71: 845-855.

Starmach K. (1966): Cyanophyta - Sinice, Glaucophyta - Glaukofity. Flora słodkowodna Polski. Vol. 2. PWN, Warszawa.

Starmach K. (1968): Chrysophyta 1. Chrysophyceae -Złotowiciowce oraz wiciowce bezbarwne - zooflagellata wolnożyjące. Flora słodkowodna Polski. Vol. 5. PWN, Warszawa.

Starmach K. (1974): Cryptophyceae, Dinophyceae, Raphidiophyceae. Flora słodkowodna Polski. Vol. 4. PWN, Warszawa-Kraków.

STARMACH K. (1989): Plankton roślinny wód słodkich. Metody badania i klucze do oznaczania gatunków występujących w wodach Europy Środkowej. PWN, Warszawa-Kraków.

Statistica for windows (Computer program manual 6.0 PL). (2002). StatSoft Inc., Tulsa.

Tavernini S., Nizzoli D., Rossetti G., Viaroli S. (2009): Trophic state and seasonal dynamics of phytoplankton communities in two sand-pit lakes at different successional stages. Journal of Limnology 68 (2): 217-228.

Trobajo R., Clavero E., Chepurnov V.A., Sabbe K., Mann D.G., Ishihara S., Cox E.J. (2009): Morphological, genetic and mating diversity within the widespread bioindicator Nitzschia palea (Bacillariophyceae). Phycologia 48: 443-459.

Waterkeyn A., Grillas P., Vanschoenwinkel B., BrenDONCK L. (2008): Invertebrate community patterns in Mediterranean temporary wetlands along hydroperiod and salinity gradients. Freshwater Biology 53 (9): 1808-1822. 